\title{
Origin and main ramifications of coeliac artery in Cerdocyon thous
}

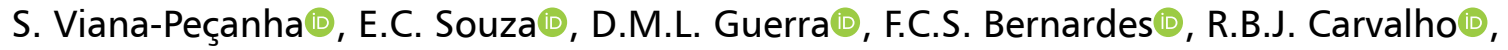 \\ P. de Souza Junior 1 , M. Abidu-Figueiredo® \\ Laboratory of Animal Anatomy, Federal University of Pampa (UNIPAMPA), Campus Uruguaiana, RS, Brazil
}

[Received: 28 May 2020; Accepted: 3 July 2020]

Background: Cerdocyon thous is the canid with the greatest geographical coverage in South America. The aim of this study was to describe the origin, skeletopy, length and main branches of the coeliac artery in C. thous.

Materials and methods: The dissections were performed on 14 cadavers of adult specimens, 6 males and 8 females, with a rostrosacral length average of $67.00 \pm$ $\pm 4.7 \mathrm{~cm}$ and $62.09 \pm 5.7 \mathrm{~cm}$, respectively. The specimens were collected dead on highways on the banks of the Atlantic Forest (Rio de Janeiro) and the Pampa biome (Rio Grande do Sul) in Brazil. The cadavers were fixed and preserved in a formaldehyde solution until dissection. The coeliac artery was dissected, the length was measured "in situ" and its main branches were recorded. The coeliac artery emerged as a single artery in all dissected animals.

Results: The average length of the coeliac artery was $1.43 \pm 0.17 \mathrm{~cm}$ in males and $1.39 \mathrm{~mm} \pm 0.24 \mathrm{~cm}$ in females, with no significant difference in this measurement between sexes. The predominant skeletopy was at the level of the second lumbar vertebra (57.1\%), positioned on average $1.43 \mathrm{~cm}$ cranially to the cranial mesenteric artery. In most individuals (92.9\%), the classic trifurcation was formed: the coeliac artery branched into the hepatic, left gastric, and lienal arteries. Only 1 male animal presented a bifurcation formed between the hepatic artery and a gastrolienal trunk.

Conclusions: These anatomical characteristics are similar to those of other species of the Canidae family, possibly due to their phylogenetic proximity. (Folia Morphol 2021; 80, 2: 331-335)

Key words: animal anatomy, cardiovascular system, crab-eating-fox, wild carnivorans

\section{INTRODUCTION}

Cerdocyon thous (C. thous), known as "crab-eating-fox", is the most widely distributed wild canid on the South American continent, populating Colombia to Uruguay. With great adaptability, it inhabits closed and open vegetation areas $[8,9,18,19]$. Body mass ranges from 5 to $9 \mathrm{~kg}$ and can measure up to $1.2 \mathrm{~m}$ from the tip of the snout to the tail [19]. The diet is based on fruits, small vertebrates, eggs, insects, and crustaceans, characterising an opportunistic omnivorous diet $[9,18]$. Cerdocyon thous is threatened by hunting, hit-and-run, and diseases transmitted by

Address for correspondence: Prof. P. de Souza Junior, Laboratory of Animal Anatomy, Rodovia BR-472, Km 595, Uruguaiana, RS, Brazil, Postal code 97501-970, tel/fax: +55 55 3911-0200, e-mail: paulosouza@unipampa.edu.br

This article is available in open access under Creative Common Attribution-Non-Commercial-No Derivatives 4.0 International (CC BY-NC-ND 4.0) license, allowing to download articles and share them with others as long as they credit the authors and the publisher, but without permission to change them in any way or use them commercially. 
Canis familiaris (C. familiaris), although its conservation is not a concern $[9,18,19]$.

The high occurrence of free-ranging $C$. thous and its high frequency in zoos and private collections makes it frequently subject to veterinary care $[8,32]$.

The coeliac artery (CA) is one of the most important arteries in the abdominal part of aorta; it is a short vessel that emerges ventrally from the abdominal aorta, at the level of the aortic hiatus of the diaphragm muscle [20]. Close to its origin, this vessel is surrounded by the coeliac plexus and ganglia. On the left, the CA forms a syntopic relationship with the stomach; on the right, with the liver and adrenal gland, and caudally with the left lobe of the pancreas $[17,20]$. The CA emits the hepatic, left gastric and lienal arteries [17].

In mixed-breed C. familiaris, the CA presents two morphological arrangements distinct from branches: classical trifurcation (formed by the hepatic artery, left gastric, and lineal), and hepatic artery and gastrolienal trunk [1]. Anatomy knowledge and possible variations in branches of the main splanchnic vessels is fundamental for planning surgeries and supports comparative studies on vascular arrangement in different species.

The aim of this study was to describe the origin, skeletopy, and main branches of the CA in Cerdocyon thous.

\section{MATERIALS AND METHODS}

Adult specimens of $C$. thous were collected dead on highways of the Atlantic Forest biome (State of Rio de Janeiro, Brazil) and in the Pampa biome (Rio Grande do Sul, Brazil) under authorisation of the Ethics Committee on Animal Experimentation (protocol 018/2017) and IBAMA/SISBIO (number 33667). Since most of the cadavers collected on highways had abdominal vessels and viscera ruptured, only specimens in perfect condition were selected for the dissection of the CA and its main branches. Thus, 14 cadavers ( 6 males and 8 females), 7 from each biome, were dissected.

Initially, the cadavers were thawed under running water, sexed, and identified by placing a plastic tag attached to the common calcaneal tendon using a string. The rostrum-sacral length of each animal was measured using a precision metal measuring tape. The tip of the snout was used as a reference for the proximal insertion of the tail. The cadavers were placed in right lateral decubitus position to access the thoracic aorta through an incision made between the $6^{\text {th }}$ and $10^{\text {th }}$ left intercostal spaces. The artery was cannulated with a number 8 or 10 urethral probe, depending on the diameter of the vessel, and was attached with a string to prevent leakage and maintain intravascular pressure. Fixation was performed by injecting a $10 \%$ formaldehyde solution through the probe in a caudal direction.

Immediately following the fixation of the cadavers, petrolatex S65 (Petrobrás Duque de Caxias Refinery [RE-DUC], Duque de Caxias/RJ) solution was injected and stained with Suvinil pigment for repletion of the arterial system. Then, the cadavers were immersed in polyethylene boxes containing $10 \%$ formaldehyde solution for to complete the latex fixation and polymerisation process.

Seven days after the latex injection, the cadavers were dissected in order to determine the origin, skeletopy, and main branches of the CA. After skin removal, two incisions were made in the abdominal wall: the first in the linea alba, starting from the xiphoid cartilage to the pubic region; the second transversely at the level of the last rib in both antimers, starting from the transverse process of the first lumbar vertebra to the linea alba. The cranial coeliac and mesenteric arteries were dissected after locating the abdominal aorta.

A digital calliper (ZAAS Precision, Amatools ${ }^{\circledR}$ ) was used to measure the distance between the centres of the origins of the coeliac and cranial mesenteric arteries and the CA length until it originated its first branch.

The mean and standard deviation of the animals' rostrosacral length, CA length, and the distance between CA and cranial mesenteric artery were calculated. These values were compared for both sexes and considered significant when $p<0.05$ using the unpaired " $\mathrm{t}$ " test. The data were analysed using the Graphapad Prism $5^{\circledR}$ Software.

\section{RESULTS}

The rostrum-sacral and CA lenght averages were higher in males (Table 1), while the distance between the coeliac and cranial mesenteric arteries was higher in females, although there was no significant difference in any comparison between sexes $(p>0.05)$.

In all dissected specimens, the CA originated ventrally from the abdominal aorta. The predominant skeletopy of the CA in C. thous occurred at the level of the second lumbar vertebra (Table 2). 
Table 1. Mean and standard deviation $(\mathrm{cm})$ of the rostrum-sacral length, length of the coeliac artery (CA) and the distance between the coeliac and cranial mesenteric arteries in Cerdocyon thous. The $\mathrm{p}$ value corresponds to that obtained in the unpaired $\mathrm{t}$-test of comparison of means between sexes

\begin{tabular}{lccc}
\hline & \multicolumn{3}{c}{ Cerdocyon thous $(\mathbf{n}=14)$} \\
\cline { 2 - 4 } & Males $(\mathbf{n}=\mathbf{6})$ & Females $(\mathbf{n}=\mathbf{8})$ & $\mathbf{P}$ \\
\hline Rostrum-sacral length & $67.0 \pm 4.79$ & $62.09 \pm 5.78$ & 0.11 \\
CA length & $1.43 \pm 0.17$ & $1.39 \pm 0.24$ & 0.78 \\
Distance between CA and & $1.48 \pm 0.20$ & $1.60 \pm 0.26$ & 0.36 \\
cranial mesenteric artery & & & \\
\hline
\end{tabular}

Table 2. Absolute and percentage frequencies of the skeletopy of the coeliac artery in Cerdocyon thous

\begin{tabular}{lccc}
\hline Skeletopy & Males $(\mathbf{n}=\mathbf{0 6})$ & Females $(\mathbf{n}=\mathbf{0 8})$ & Total $(\mathbf{n}=\mathbf{1 4})$ \\
\hline L1 & $2(33.3 \%)$ & - & $2(14.3 \%)$ \\
L1-L2 & $1(16.7 \%)$ & $3(37.5 \%)$ & $4(28.6 \%)$ \\
L2 & $3(50.0 \%)$ & $5(62.5 \%)$ & $8(57.1 \%)$ \\
\hline
\end{tabular}

Although the CA in C. thous presented a variable skeletopy between the individuals, there was no statistical difference between sexes $(p=0.05)$.

In 13 specimens, the classic trifurcation was formed: the CA originated the hepatic, left gastric and lienal arteries (Fig. 1). Only 1 male animal presented a bifurcation formed between the hepatic artery and a gastrolienal trunk (Fig. 2).

\section{DISCUSSION}

\section{Origin}

The CA emerged ventrally from the abdominal aorta, close to the aortic hiatus of the diaphragm, similar to what is described in different mammals $[1-3,10,22,23,27,33]$. However, in Bubalus bubalis foetuses [24] and in 33\% of Lycalopex gymnocercus specimens [22], the origin of the CA occurred in the thoracic aorta. Despite phylogenetic proximity to $L y$ calopex gymnocercus, no coeliac arteries originating in the thoracic aorta were found in the sampling of C. thous from the present study.

Some studies have noted variations in the emergence of the CA in some species of mammals and mention the presence of a common trunk formed by the coeliac and cranial mesenteric arteries called the coeliac-mesenteric trunk. It was reported with Ovis aries [21], Bubalus bubalis [24], Capra aegagrus hircus [13], Myocastor coypus [23], C. familiaris [30], Felis catus [29], Didelphis albiventris [11], and humans [15].

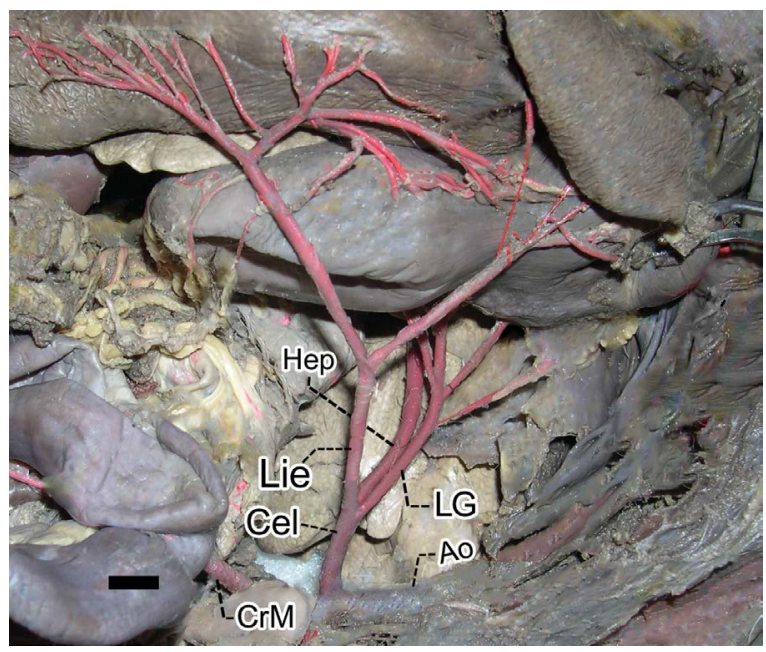

Figure 1. The aorta $(\mathrm{Ao})$, cranial mesenteric $(\mathrm{CrM})$ artery and coeliac artery (Cel) and its main branches (classic trifurcation): hepatic (Hep), left gastric (LG) and lienal (Lie) arteries in a female, adult, specimen of Cerdocyon thous. Scale bar: $10 \mathrm{~mm}$.

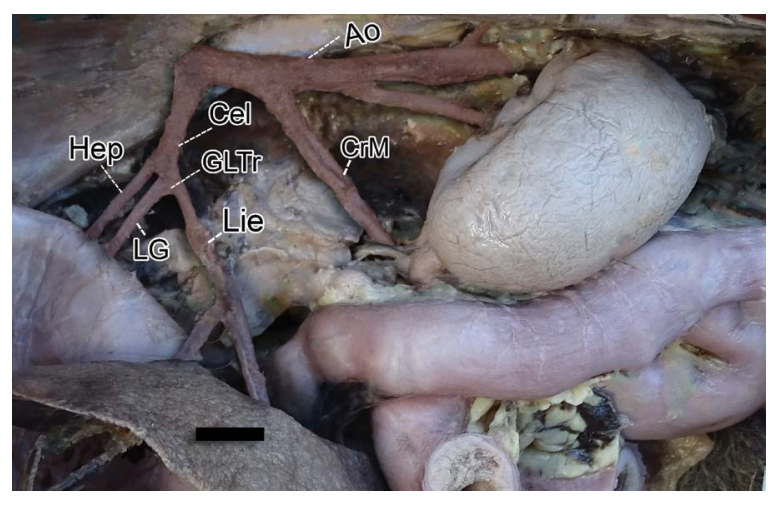

Figure 2. The aorta $(\mathrm{Ao})$, cranial mesenteric ( $\mathrm{CrM})$ artery and coeliac artery (Cel) and its main branches. In this specimen, an adult male Cerdocyon thous, coeliac artery originated a gastrolienal trunk (GLTr) and a hepatic artery (Hep); the gastrolienal trunk bifurcated into lienal (Lie) and left gastric (LG) arteries. Scale bar: $10 \mathrm{~mm}$.

In humans, another arrangement has been described: the formation of the coeliac-bimesenteric trunk, formed by the coeliac, superior mesenteric, and inferior mesenteric arteries [7, 26].

Regarding the incidence in mammals, the coeliac-mesenteric trunk was divided into three groups: a group with a regular or preponderant incidence, observed in Cavia porcellus; a group with frequent incidence, observed in Ovis aries; and a group with a low or zero incidence observed in Castor fibre, Erinaceus europaeus, Mesocricetus auratus, and Mus musculus [31]. In canids, the occurrence of coeliac-mesenteric trunk is described only in C. familiaris [30], not being found in L. gymnocercus [22] or C. thous. 
Table 3. Summarisation of common skeletopy, average length and primary branches of coeliac artery in species of the order Carnivora

\begin{tabular}{lccccc}
\hline Species & Family & N & $\begin{array}{c}\text { Common } \\
\text { skeletopy }\end{array}$ & Length & Branches \\
\hline C. thous & Canidae & 14 & $\mathrm{~L} 2$ & $1.41 \mathrm{~cm}$ & Hepatic, left gastric and lienal arteries \\
L. gymnocercus [22] & Canidae & 15 & $\mathrm{~L} 2$ & - & Hepatic, left gastric and lienal arteries \\
V. vulpes [12] & Canidae & 06 & $\mathrm{~L} 1$ & - & Gastrolienal trunk and hepatic artery \\
C. familiaris [1] & Canidae & 30 & $\mathrm{~L} 1$ & $0.98 \mathrm{~cm}$ & Gastrolienal trunk and hepatic artery or hepatic, left gastric and lienal arteries \\
M. martes [34] & Mustelidae & 01 & - & - & Gastrolienal trunk and hepatic artery \\
M. p. furo [13] & Mustelidae & - & - & - & Hepatic, left gastric and lienal arteries \\
N. nasua [5] & Procyonidae & 04 & $\mathrm{~L} 1$ & - & Hepatic, left gastric and lienal arteries \\
F. catus [33] & Felidae & 30 & $\mathrm{~L} 1$ & $1.30 \mathrm{~cm}$ & Gastrolienal trunk and hepatic artery or hepatic, left gastric and lienal arteries \\
L. pardalis [28] & Felidae & 02 & - & - & Hepatic, left gastric and lienal arteries \\
\hline
\end{tabular}

\section{Skeletopy}

In domestic carnivores, the coeliac artery has a predominant origin at the level of the first lumbar vertebra (Table 3) [1, 29, 33], although origin points as cranial as the $13^{\text {th }}$ thoracic vertebra or as caudal as the $2^{\text {nd }}$ lumbar vertebra are often described [1, 25, 33 ]. In the wild canid L. gymnocercus, the predominant skeletopy of the CA was at the level of the $2^{\text {nd }}$ lumbar vertebra, varying cranially to the $1^{\text {st }}$ lumbar [22], similar to the results obtained in the sampling of C. thous in this research. In other carnivores, including C. familiaris and Felis catus as well as wild canids Vulpes vulpes and procyonid Nasua nasua, the skeletopy was at the level of the first lumbar $[1,5,12,33]$.

Getty et al. [17] reported that the CA appears at the level of the $17^{\text {th }}$ and $18^{\text {th }}$ thoracic vertebra in Equus ferus caballus, at the level of the $1^{\text {st }}$ lumbar vertebra in Bos taurus and Ovis aries, between the $1^{\text {st }}$ and $2^{\text {nd }}$ lumbar vertebra in goat [16], and between the last thoracic vertebra and the $1^{\text {st }}$ lumbar vertebra in Sus domesticus. In Oryctolagus cuniculus, the coeliac artery's level predominates between the $13^{\text {th }}$ thoracic vertebra and the $1^{\text {st }}$ lumbar [2], ventrally to the $1^{\text {st }}$ lumbar vertebra in Cavia porcellus [17], and the coeliac trunk appears at the level of the $12^{\text {th }}$ thoracic vertebra in humans [26].

Reports of CA length measurements are still scarce. In the C. familiaris it measures around $2 \mathrm{~cm}$ [14], $1.3 \mathrm{~cm}$ in Felis catus [33], and about $1.4 \mathrm{~cm}$ in C. thous. Regarding the distance between the origins of the coeliac and cranial mesenteric arteries, it was described as $3 \mathrm{~mm}$ in Bubalus bubalis foetuses, ranging from 1.8 to $5 \mathrm{~mm}$ [24]. In humans, it was $12 \mathrm{~mm}$, ranging from 3 to $23 \mathrm{~mm}$ [4]. The mean value found in Lycalopex gymnocercus was $6.66 \mathrm{~mm}$, had a moderate correlation with the animal's length [22], and was smaller than in the $C$. thous specimens analysed.

\section{Main branches}

The classic trifurcation of the CA into hepatic, left gastric and lienal arteries was the most prevalent arrangement in $C$. thous, similar to that registered in C. familiaris, Oryctolagus cuniculus, Myocastor coypus, and Galea spixii [1, 2, 10, 27]. The bifurcation in a hepatic artery and gastrolienal trunk found in a single specimen of $C$. thous of this sampling was also reported as sporadic in C. familiaris [1, 14]. However, this bifurcation was found in almost half of Felis catus [33]. In Oryctolagus cuniculus, unlike in other species, the CA emitted only one arrangement: the lienal artery and then the left gastric artery, which continued to be hepatic [2]. In Hystrix cristata and Dildelphis albiventris, the CA was divided into only two branches: the lienal artery and the hepatic artery in all animals studied $[6,11]$.

\section{CONCLUSIONS}

It can be concluded that the CA in C. thous originates as a single artery in the ventral face of the $a b$ dominal aorta, predominantly at the level of the second lumbar vertebra, about $1.5 \mathrm{~cm}$ from the cranial mesenteric artery, cranially. The artery measures about $1.4 \mathrm{~cm}$ until the predominant classic trifurcation occurs, although a bifurcation variant can be verified. These anatomical characteristics are similar to those described in other canids, possibly as an expression of the evolutionary proximity of these species.

\section{Funding}

Research Support Foundation of Rio Grande do Sul (FAPERGS), National Council of Technological and Scientific Development (CNPq), Rio de Janeiro State Research Foundation (FAPERJ) and Coordination of Superior Level Staff Improvement (CAPES) Finance Code 001. 


\section{REFERENCES}

1. Abidu-Figueiredo $M$, Dias GP, Cerutti $S$, et al. Variations of celiac artery in dogs: anatomic study for experimental, surgical and radiological practice. Int J Morphol. 2005; 23(1), doi: 10.4067/s0717-95022005000100007.

2. Abidu-Figueiredo M, Xavier-Silva B, Cardinot T, et al. Celiac artery in New Zealand rabbit: anatomical study of its origin and arrangement for experimental research and surgical practice. Pesquisa Veterinária Brasileira. 2008; 28(5): 237-240, doi: 10.1590/s0100-736x2008000500002.

3. Amadori A, Birck AJ, Fidelpho AL, Guimarães GC, Peres JÁ, Souza RAM. Origem e distribuição da artéria celíaca em veado catingueiro (Mazama gouazoubira). Revista Cientifica Eletrônica Medicina Veterinária [Internet]. 2012 Jul. 10(19) [Portuguese]. http://faef.revista.inf. br/imagens_arquivos/arquivos_destaque/NnwiPElvFhCS7oy_2013-6-24-12-3-16.pdf (cited 2020 Mar 03).

4. Araujo Neto SA, Franca HA, de Mello Júnior $C F$, et al. Anatomical variations of the celiac trunk and hepatic arterial system: an analysis using multidetector computed tomography angiography. Radiol Bras. 2015; 48(6): 358-362, doi: 10.1590/0100-3984.2014.0100, indexed in Pubmed: 26811552.

5. Assunção $M$, Oliveira $T$, Oliveira $T$, et al. Comparative Anatomy of Abdominal Aorta in Coati (Nasua nasua). Int J Adv Engineer Res Sci. 2019; 6(2): 259-267, doi: 10.22161/ijaers.6.2.32.

6. Atalar $\mathrm{O}$, Yilmaz $\mathrm{S}$. The branches of the arteria celiaca in the porcupine (Hystrix cristata). Vet Med. 2012; 49(No. 2): 52-56, doi: 10.17221/5675-vetmed.

7. Bergman RA, Thompson SA, Afifi AK, Saadeh FA. Compendium of human anatomic variation: Catalog, Atlas and World Literature. Urban \& Schwarzenberg, Munich 1988.

8. Cheida CC, Nakano-Oliveira E, Fusco-Costa R, RochaMendes F. (eds). Ordem Carnivora. In: Reis NR, Perachi AL, Pedro WA, Lima IP (eds). Mamíferos do Brasil. Nelio R. dos Reis, Londrina 2006: 231-276.

9. Courtenay O, Maffei L. Crab-eating fox Cerdocyon thous (Linnaeus, 1766). In: Sillero-Zubiri C, Hoffmann M, Macdonald DW, editors. Canids: Foxes, Wolves, Jackals and Dogs. Status Survey and Conservation Action Plan. IUCN/ SSC Canid Specialist Group, Cambridge 2004: 32-38.

10. Culau POV, Azambuja RC, Campos R. Ramos colaterais viscerais da aorta abdominal em Myocastor coypus (nutria). Acta Scientiae Veterinariae. 2008; 36(3): 241-247.

11. Culau $P$, Reckziegel $S$, Goltz $L$, et al. A artéria celíaca em Didelphis albiventris (gambá). Acta Scientiae Veterinariae. 2018; 38(2): 121, doi: 10.22456/1679-9216.16589.

12. Dogan GK, Dalga S, Akbulut Y, et al. Kızıl Tilkilerde (Vulpes vulpes) Arteria Celiaca ve Dalları Üzerinde Bir Çalışma. Harran Üniversitesi Veteriner Fakültesi Dergisi. 2019; 8(2): 168-172, doi: 10.31196/huvfd.667680.

13. Evans H, An MQ. Anatomy of the Ferret. In: Fox JG, Marini RP (eds) Biology and Diseases of the Ferret, 3rd ed. John Wiley \& Sons, Philadelphia 2014: 23-67.

14. Evans HE, Lahunta A. Miller's anatomy of the dog. 4th ed. Elsevier Health Sciences, New York 2013.

15. Fakoya AO, Aguinaldo E, Velasco-Nieves NM, et al. A unique communicating arterial branch between the celiac trunk and the superior mesenteric artery: a case report. Open Access Maced J Med Sci. 2019; 7(13): 2138-2141, doi: 10.3889/oamjms.2019.562, indexed in Pubmed: 31456840.

16. Ferreira F, Miglino $M$, Silva F, et al. Origens e ramificações das artérias mesentéricas cranial e caudal em fetos de caprinos da raça Saanen (Capra hircus - Linnaeus, 1758). Braz J Vet Res Animal Sci. 2001; 38(2), doi: 10.1590/s141395962001000200005.

17. Getty R, Sisson S, Grossman JD. Anatomia dos animais domésticos. 5th ed. Vol. 1. Guanabara Koogan, Rio de Janeiro 1986.

18. Hunter L. Carnivores of the World. Princeton University Press, Princeton 2011.

19. Kasper CB, Trinca CS, Sanfelice D, Mazim FD, Trigo TC. Os carnívoros. In: Gonçalves GL, Quintela FM, Freitas TRO (eds). Mamíferos do Rio Grande do Sul. Pacartes,, Porto Alegre 2014: 161-190.

20. König HE, Liebich HG. Anatomia dos animais domésticos: texto e atlas colorido. 6th ed. Artmed, Porto Alegre 2016.

21. Langenfeld M, Pastea E. Anatomical variants of the celiac artery in the sheep, with special reference to the celiomesenteric arterial trunk. Anat Anz. 1977; 142(3): 168-174, indexed in Pubmed: 603064.

22. Leão-Neto LF, Souza EC, Rodriguez E, et al. Esqueletopia e topografia da artéria celíaca no Lycalopex gymnocercus (Fischer, 1814). Revista Acadêmica Ciência Animal. 2019; 17: 1, doi: 10.7213/1981-4178.2019.17007.

23. Machado GV, Souza JR, Gonçalves PR, et al. artéria celíaca e seus ramos no ratão-do-banhado (Myocastor coypus — Rodentia: Mammalia). Biotemas. 2002; 15(2): 44-52, doi: $10.5007 / \% 25 x$

24. Machado M, Miglino M, Carbal V, et al. Origem das artérias celíaca e mesentérica cranial em bubalinos (Bubalus bubalis, L. 1758). Brazi J Vet Res Animal Sci. 2000; 37(2), doi: 10.1590/s1413-95962000000200002.

25. Niza MM, Vilela CL, Ferreira AJA, et al. Irrigação arterial hepática em canídeo. Revista Portuguesa de Ciências Veterinárias. 2003; 98(546): 69-76.

26. Nonent M, Larroche $P$, Forlodou $P$, et al. Celiac-bimesenteric trunk: anatomic and radiologic description - case report. Radiology. 2001; 220(2): 489-491, doi: 10.1148/radiology.220.2.r01au34489, indexed in Pubmed: 11477258.

27. Oliveira G, Oliveira R, Bezerra F, et al. Origem e distribuição da artéria celíaca em preás (Galea spixii Wagler, 1831). Ciência Animal Brasileira. 2017; 18(0), doi: 10.1590/10896891v18e-32918.

28. Pinheiro $L$, Araújo $E$, Lima $A$, et al. Os ramos colaterais da aorta abdominal em jaguatirica (Leopardus pardalis). Pesquisa Veterinária Brasileira. 2014; 34(5): 491-495, doi: 10.1590/s0100-736x2014000500018.

29. Roza MS, Pestana FM, Silva BX, et al. Tronco Celiaco-Mesentérico em Gato. Revista Portuguesa de Ciências Veterinárias. 2009; 104(569): 83-86.

30. Schmidt D, Schoenau L. Origem das artérias celíaca e mesentérica cranial por tronco comum em cão. Ciência Rural. 2007; 37(2): 408-411, doi: 10.1590/s010384782007000200017.

31. Schultz W. Der Magen-Darm-Kanal der Monotremen und Marsupialier. In: Helmeke JG, Starck D, Wermuth H. (eds). Handbuch der Zoologie. Walter de Gruyter, Berlin 1976: 1-117.

32. Silva A, Feliciano M, Motheo T, et al. Mode B ultrasonography and abdominal Doppler in crab-eating-foxes (Cerdocyon thous). Pesquisa Veterinária Brasileira. 2014; 34(suppl. 1): 23-28, doi: 10.1590/s0100-736x2014001300005.

33. Xavier-Silva B, Roza MS, Babinski MA, et al. Morfometria, origem e esqueletopia da artéria celíaca no gato doméstico. Rev Bras Med Vet. 2013; 35(3): 253-259.

34. Yousefi M. Ramification of Celiac artery in the pine marten (Martes martes). Iranian J Vet Sci Tech. 2016; 8(2): 60-65, doi: $10.22067 /$ veterinary.v8i2.54842. 